\title{
Türkçe Dersi Öğretim Programındaki Kök Değerler Çerçevesinde Aytül Akal
} Masallarunun İncelenmesi

\section{Arş. Gör. Sevgen Özbaşı ${ }^{1 *}$}

Gelis tarihi: 06.04 .2020

Kabul tarihi: 07.05.2020

\section{Atıf bilgisi:}

IBAD Sosyal Bilimler Dergisi

Sayı: $8 \quad$ Sayfa: $178-192$

Yıl: 2020 Dönem: Güz

This article was checked by iThenticate. Similarity Index 6\%

Bu makalede araştırma ve yayın etiğine uyulmuştur.

${ }^{1}$ Başkent Üniversitesi, Türkiye, sozbasi@baskent.edu.tr, ORCID ID 0000-0003-4406-675X

\footnotetext{
* Sorumlu yazar
}

ÖZ

Bilişsel, duyuşsal, dilsel, toplumsal gelişim ve kişilik gelişiminin sağlıklı bir biçimde ilerleyebilmesi ve insanın "birey" olarak kendini ifade edebilmesi için çocukluk döneminde gereksinimlerine uygun nitelikte uyaranlarla etkileşimde bulunması gerekir. Çocuğun toplumsallaşma sürecinde farklı yaşam deneyimlerine tanıklık etmesi onun dilsel, bilişsel sosyal becerilerinin gelişmesinde yardımcıdır. $\mathrm{Bu}$ süreç çocuğun, evrensel ve ulusal değerleri özümseyip duyarlık ve değerler eğitimi kazanması açısından önemlidir. Bu noktada, çocuğa yardımcı olabilecek en temel ve en etkili araçlar çocuk edebiyatı ürünleridir. Benlik gelişimi, duyarlık ve değerler eğitiminin temellerinin atıldığı okulöncesi dönemlerde, çocuklar için hazırlanan yapıtların niteliği daha da önem taşımaktadır. Bu dönemde çocukların daha çok ilgi gösterdiği kitapların masal kitapları olmasından dolayı bu çalışmada Aytül Akal tarafindan yazılan çağdaş masallar, Türkçe Dersi Öğretim Programında belirtilen "kök değerler" çerçevesinde irdelenmiştir. Betimsel nitelik taşıyan bu çalışmada veriler doküman incelemesi yoluyla toplanmıştır. İnceleme sonucunda masalların "adalet, dostluk, dürüstlük, özdenetim, sabır, saygı, sevgi, sorumluluk, vatanseverlik, yardımseverlik" kök değerlerinin tamamını içerdiği belirlenmiştir. Bu bağlamda yazarın masallarına yönelik Türkçe Dersi Öğretim Programında yer alan kök değerleri aktaran ileti ve örnekler içerdiği; bu değerler aracilığıyla çocukların değerler eğitimi sürecine katkı sağlayabileceği söylenebilir.

Anahtar Kelimeler: Türkçe Dersi Öğretim Programı, kök değerler, çocuk edebiyatı, Aytül Akal, çağdaş masallar. 


\section{Analysis of Aytül Akal's Tales within the Framework of the Core Values in the National Turkish Language Curriculum}

\section{Res. Assist. Sevgen Özbaşı ${ }^{1^{*}}$}

First received: 06.04.2020

Accepted: 07.05.2020

\section{Citation:}

IBAD Journal of Social Sciences

Issue: 8

Year: 2020

Pages: 178-192

Session: Fall

This article was checked by iThenticate. Similarity Index 6\%

${ }^{1}$ Başkent University, Turkey, sozbasi@baskent.edu.tr,

ORCID ID 0000-0003-4406-675X

* Corresponding Author

\begin{abstract}
For children to have a healthy process of cognitive, emotional, linguistic, and social developments as well as express themselves as an individual, they need to be engaged in various stimuli in appropriate. Children go through different experiences during the socialition process and these exprerience help them develop their linguistic, cognitive, and social skills. This process is important for them to absorb universal and national values and gain sensitivity. At this point, the most basic and effective tools that can help children are literary works of children's literature. The quality of the works prepared for children is even more significant in preschool periods when the foundations of self-development, sensitivity and values education are established. Since the books that children showed more interest in this period were tale books, modern tales written by Aytül Akal were analyzed within the framework of the "core values" specified in the National Turkish Language Curriculum. In this descriptive study, the data were collected through document review and analyzed via systematic content analysis. Results show that the analyzed tales contain all 10 core values of justice, friendship, honesty, self-control, patience, respect, love, responsibility, patriotism and benevolence. In this context, it can be stated that the author's tales include moral messages and examples reflecting the core values emphasized in Turkish language education; therefore, they can contribute to children's value education process.
\end{abstract}

Keywords: National Turkish Language Curriculum, core values, children's literature, Aytül Akal, modern tales. 


\section{GİRIŞ}

Değer kavramı, -tek ve ortak bir tanıma sahip olmamakla birlikte- Türkçe Sözlük’te (2019) "Bir şeyin önemini belirlemeye yarayan soyut ölçü, bir şeyin değdiği karşıllk" olarak tanımlanmıştır. Değer bir toplumun tarihinden süzülüp gelen inanç, gelenek, görenek, anlayış, dolayısıyla kültürel birikimlerinin toplamıdır. Tarihsel süreç içinde bu değerlerin gelişip olgunlaşması, toplumda daha çok ortak değer oluşturarak insanların kenetlenmesini sağlar.

Oğuzkan'a (1993, s.33) göre değer, bir varlı̆̆ın ruhsal, toplumsal, ahlaksal ya da estetik yönden taşıdığı düşünülen yüksek ya da yararlı niteliktir. Bu bağlamda değerler eğitimi de değerlerin farkında, kişiliği gelişmiş, davranışları olgunlaşmış bireyler yetiştirmek amacıyla okulda verilen sistemli eğitim bütünü olarak tanımlanmaktadır (Kantar, 2014). Değerlerin kapsamı içerisinde hem ulusal/toplumsal hem de evrensel değerler yer almaktadır. Toplumsal değerler; bir toplumun bireylerinin zaman içinde oluşturduğu, önemli ve değerli saydığı, paylaştığı ve yaşatmaya çalıştığı, toplumsal bütünleşmeyi ve dayanışmayı sağlayan, toplumdan topluma farklılık gösteren, o toplum için vazgeçilmez olmakla birlikte zaman içinde değişim de gösterebilecek değerlerdir. Ulusal değeler de toplumsal değerler içinde önemli bir yere sahiptir. Konukseverlik, yardımseverlik, yurtseverlik, bağımsızlık vb. toplumsal ve ulusal değerlerden birkaçıdır. Kişinin toplumsallaşabilmesi için yalnızca kendi toplumunun değerlerini bilmesi yeterli değildir. İnsanlık yararını ve mutluluğunu gözetmesi için geniş insan topluluklarınca değer olarak kabul edilmiş, bütün toplumlarda kendine yer bulmuş, zaman içinde değişiklik göstermeyecek, tüm insanlığı ilgilendiren ve insanlık adına güzellikler yaratılmasına katkıda bulunacak evrensel nitelik kazanmış değerleri de içselleştirmiş olması gerekir. Sevgi, saygı, hoşgörü, barış, dürüstlük, adalet, sorumluluk, dostluk, bilimsellik, estetik gibi değerler evrensel niteliktedir. İçinde yaşadığı toplum ve diğer toplumlarla iyi, sağlıklı ve uyumlu ilişkiler içinde olabilmeleri için çocuklara küçük yaşlardan başlayarak kendi toplumsal değerlerini ve evrensel boyutta kabul görmüş değerleri öğretmek/sezdirmek gerekir (Aslan, 2019, s.56).

Temeli ailede atılan değerler eğitimi, çocuklar okula başladıklarında resmî ve sistemli bir biçimde örgün eğitim içerisinde sürdürülmektedir. Okulların amacı hem temel değerleri özümsemiş hem de akademik anlamda başarılı bireyler yetiştirmektir. Yazıcı (2006, s.499) okullarda verilen değerler eğitimin önemini vurgulayarak eğitim-öğretimleri boyunca öğrencilerin yalnızca bilişsel ve devinişsel kazanımlarına odaklanılırsa, onların değer ve tutum gibi duyuşsal kazanımlardan yoksun kalacaklarını belirtmiş; böyle bir durumun da toplumsal birlik ve bütünlüğün oluşmasına, sağlıklı bir toplum yapısı kurulmasına ket vuracağını ifade etmiştir. Bunun önüne geçmek için tüm derslere ilişkin öğretim programlarında temel/kök değerlerin kazanımına yer verilmiştir. Küreselleşmeyle birlikte daha da önem kazanan ve eğitim sistemlerine giren değerler eğitimi, Türkiye'de 2004 yılında başlayan eğitim programı geliştirme çalışmalarında yer almıştır. MEB Türkçe Dersi Öğretim Programında $(2019$, s.4) değerler ve değerler eğitimine ilişkin şu bilgiler aktarılmıştır:
"Değerlerimiz öğretim programlarının perspektifini oluşturan ilkeler toplamıdır. Kökleri geleneklerimiz ve dünümüz içinde, gövdesi ve dalları bu köklerden beslenerek bugünümüze ve yarınlarımıza uzanmaktadır. Temel insani özelliklerimizi oluşturan değerlerimiz, hayatımızın rutin akışında karşılaştı̆̆ımız sorunlarla başa çıkmada eyleme geçmemizi sağlayan gücün kaynağıdır. Eğitim sistemi sadece akademik açıdan başarılı, belirlenmiş bazı bilgi, beceri ve davranışları kazandıran bir yapı değildir. Temel değerleri benimsemiş bireyleri yetiştirmek aslî görevidir; yeni neslin değerlerini, alışkanlıklarını ve davranışlarını etkileyebilmelidir. Eğitim sistemi değerleri kazandırma amacı çerçevesindeki amacını, öğretim programlarını da kapsayan eğitim programıla yerine getirir. Eğitim programı, eğitim sisteminin tüm unsurları göz önünde bulundurularak oluşturulur. Öğretim programlarında bu anlayışla değerler, ayrı bir program veya öğrenme alanı olarak görülmemiş; tam aksine ögretim programlarının her birinde ve her bir biriminde yer almıştır. Değerlerimiz, öğretme-öğretme sürecinde hem kendi başlarına hem ilişkili olduğu alt değerlerle birlikte ele alınarak hayat bulacaktır."

Yukarıda bilgilere ek olarak, Talim ve Terbiye Kurulu Başkanlığınca (2017) yapılan basın duyurusunda, öğretim programlarında öğrencilere aktarılması amaçlanan kök değerlerin "adalet, dostluk, dürüstlük, 
özdenetim, sabır, saygı, sevgi, sorumluluk, vatanseverlik, yardımseverlik" olduğu paylaşılmış; yenilenen ögretim programlarına bu kök değerler eklenerek bunlarla ilişkili tutum ve davranışlar belirtilmiştir.

Aslan'a (2019, s.57) göre değerler, yaşamda nelerin önemli olduğuyla ilgili olarak insanların benimsediği inançlar dizgesidir. Duyuşsal alan içinde yer alan değerler, kişinin geçirdiği yaşantılar sonucunda kazanılır. İnsanların açık ve belirgin bir biçimde çeşitli değerlere sahip olmaları; bir olay karşısında ne yapmaları/nasıl davranmaları gerektiğini bilmeleri; kendi ölçütlerini oluşturmaları, taraflarını belirlemeleri, kendilerini gerçekleştirebilmeleri; yaşamlarını ilkeli, tutarlı, barışçıl bir biçimde yönlendirebilmeleri ve toplumla aralarında güçlü bir bağ oluşturabilmeleri bakımından gereklidir. İnsanın duyarlı olması toplumsal ve evrensel değerleri bilmesine, bunların önemine inanmasına bağlıdır. $\mathrm{Bu}$ yönüyle değerler eğitimi, karakter eğitimiyle ilişkilendirilebilir. Ekşi (2003), değerler eğitimini karakter eğitimi olarak ele almış; karakter eğitiminin yaygın olarak öğrencilerde temel etik değerleri anlama, onlara bağl1lık ve değerlere göre davranma eğilimi geliştirme süreci olduğunu belirtmiştir.

Değerler eğitimi sırasında karşılaşılabilecek sorunları önlemek için öncelikle etkili bir değerler eğitimi programı hazırlanmalıdır. Bu programın oluşturulma sürecinde eğitim-öğretimin içerisinde yer alan bileşenler yer almalıdır. Dolayısıyla en başta öğretmenlerin "program nelerden oluşmalı, hangi değerleri kapsamalı, bu süreç nasıl işlemeli ve nasıl uygulanmalı" gibi sorulara yanıt bulmaları ve bu yanıtlar doğrultusunda programı yapılandırmaları gerekmektedir (Bishop 1993'ten akt. Yazıc1 2006, s.507). Öğretim programlarındaki konu ve kazanımlara uygun olarak hazırlanan, eğitimde birliği sağlamak adına en temel ve kolay ulaşılabilir kaynak olan ders kitaplarında değerler eğitimi süresince de yararlanılmaktadır. Ancak bu noktada, ders kitaplarının niteliği ve özellikle Türkçe dersi için kullanılan metinlerin içeriği büyük önem taşımaktadır. Değerler eğitimi sürecinde yalnızca ders kitaplarındaki metinleri kullanmak yeterli gelmemekte; başka kaynaklarda da yararlanmak gerekmektedir. Sanatçılar tarafindan çocuğa görelik ve çocuk gerçekliğini gözeterek hazırlanmış, yaş ve gelişim düzeyine uygun çocuk edebiyatı kitaplarıyla -bu kitaplardan alınan öykü ve masallarla- işlenen bir dersin, öğrencilerin değer eğitimi sürecine olumlu yönde katkı sağlaması kaçınılmazdır. Çocuk edebiyatının değer eğitimi ve öğretimi sürecinde etkili olması, çocuk okurların karakterlerle kurduğu özdeşimden kaynaklanmaktadır.

Çocukların değerleri içselleştirmesiyle ilgili olarak Jarolimek (1990 akt. Çelik ve Buluç 2018, s.70), ilkokullarda uygulanan değerler eğitimi sürecinde çocukların yaşına uygun olan öykü, şiir, roman gibi yazınsal türleri kaynak olarak kullanmanın önemini vurgulamış ve çocuk edebiyatı yapıtlarının değer öğretimi sürecini kolaylaştırdığını belirtmiştir. Çelik ve Buluç (2018, s.70), değer eğitimi için çocuk edebiyatı ürünlerini kullanmanın yanında disiplinler arası bir yaklaşımla derslerde yaratıcı drama etkinlikleri yaptırmanın da etkili olabileceğini savunmuştur. Yaratıcı dramanın temelinde uygulama olduğu için öğrencinin bir rol içinde belli davranışlar sergilemesi, oynadığı karakterle özdeşleşmesi gibi durumlar değerlerin benimsenmene yardımcı olabilir.

Değerler, çocuklara öncelikle bu konuda en iyi modeller olan ve çocukların yaşamlarının odağında yer alan anne-baba ile öğretmenler tarafından bilişsel olarak öğretilmelidir. Ancak duygular gibi değerlerin de gerek aile gerekse okul ortamında yalnızca bilişsel olarak öğretilmesi, çocuğun o değerleri özümsemesi ve kişiliğinin bir parçası yapabilmesi içi yeterli olmayabilir. Çocuğun bu değerleri tanıması, önemsemesi, benimsemesi ve davranışa dönüştürebilmesi için olayları duyuları ve duygularıyla da algılaması gerekir; çünkü yalnızca içselleştirilmiş davranışlar, bilinçli yönelimlerle yaşamsal kılınıp uygulanabilir. $\mathrm{Bu}$ bağlamda nitelikli eğitim, insanın bilişsel becerilerini olduğu kadar duyuşsal becerilerini de geliştirmek durumundadır (Sever, 2015; Aslan, 2019, s.57).

Değerler eğitimi -daha önce de belirtildiği gibi- eğitimin duyuşsal alanını hedef alır; bu duyuşsal alan davranışlarının gelişmesi/geliştirilmesi uzun ve sistemli bir süreçte gerçekleşir. Bu sürecin etkili ve verimli bir şekilde ilerleyebilmesinde edebiyat yapıtları önemli ve işlevsel araçların başında gelmektedir. Edebiyat yapıtları insanın birçok gereksinimi karşılamasının yanında, insan yaşamına anlam katan değerlerin duyumsatılmasına ve yeni değerlerin yaratılmasına olanak sağlar. Kavcar'a $(1999$, s.6) göre edebiyat yapıtları insanın iç dünyasını yumuşatır; sevgi, iyilik, dostluk, hoşgörü, dayanışma gibi insana özgü değer ve özellikleri pekiştirir; bunların yerleşip kökleşmesini, toplumsal yaşamın gerektirdiği değerlerin benimsenmesine yardımcı olur. Kısacası, edebiyat yapıtları insanın 'insanlaşmasını' sağlayan temel araçlardandır. 
Çocuğun duygu ve düşünce dünyasının sağllk bir biçimde kurulup geliştirilmesinde önemli rolü olan çocuk edebiyatı ürünleri, insana ve yaşama ilişkin pek çok durumun yanı sıra toplumsal ve evrensel boyuta ulaşmış çeşitli değerleri de yansıtır. Çocuk, bu nitelikteki yapıtlar aracılı̆̆ıyla hem kendi toplumunun hem de diğer toplumların değerlerini öğrenerek daha geniş anlamda toplumsallaşır (Aslan, 2019, s.60). Çocukluk dönemi özdeşimin en etkili olduğu dönemdir ve çocuklar için çocuk kitaplarındaki karakterlerle özdeşleşmek çok önemlidir. Özdeşleşme, çocuğun rol model olarak gördügü bireylerle etkileşir ve çocuğun karakter oluşumunda rol oynar. Çocuklar karakterlerle birlikte yaşamın sorunlarıyla yüzleşir ve onlara çözümler üretir. Böylece farkında bile olmadan toplumsal değerleri öğrenmiş olur. Bu nedenle kitaplardaki karakterlerde çocuk için kendinden bir şeyler bulabilmelidir. Nitelikli çocuk edebiyatı ürünleri çocukların öğrenme ve gelişme süreçlerinde dilsel ve görsel bir uyaran olarak yer edinmesi gereken, olumlu benlik gelişiminin en önemli aracı ve destekleyicileridir.

Sözlü kültür ürünleri arasında önemli bir yeri olan ve çocuk edebiyatında varlığını sürdüren en eski yazınsal türlerden biri de masaldır. Türkçe Sözlük’te masal “ Genellikle halkın yarattığı, hayale dayanan, sözlü gelenekte yaşayan, çoğunlukla insanlar, hayvanlar ile cadı, cin, dev, peri vb. varlıkların başından geçen olağanüstü olayları anlatan edebî tür" olarak tanımlanmıştır. Saim Sakaoğlu Masal Araştırmaları kitabında masalı "Kahramanlarından bazıları hayvanlar ve doğaüstü varlıklar olan, olayları masal ülkesinde cereyan eden, hayal ürünü olduğu halde dinleyicileri inandırabilen bir sözlü anlatım türüdür"' biçiminde açıklamıştır.

Masal kitapları, çocuk edebiyatı ürünleri arasında öykü ve roman türlerinden önce çocuğun etkileşim kurduğu ilk kitaplardandır. Masallar, çocukların dilsel ve bilişsel gelişimine katkı sağlamanın yanında, onların düş dünyasını zenginleştirerek yaratıcılıklarını da destekleyebilir. Ayrıca anne ve babası tarafindan çocuğa okunan ya da anlatılan masallar, yaşamda çocuk için en değerli kişilerle bir anı paylaşma, zaman geçirme, sevgi ve güven bağını sağlamlaştırma gibi olumlu durumların oluşmasına yardımcı olması bakımından da önemlidir.

Her çocuğun okuma eğilimi ve kitaplara yönelimi, başta aile ve sosyal çevresi olmak üzere bazı değişkenler doğrultusunda farklılık gösterse de araştırmacılar tarafından çocukların okuma eğilimleri noktasında birtakım belirlemeler söz konusudur. Bu belirlemeler -kesin olmamakla birlikte- çocukların okuma eğilimleri ve hangi dönemde ne tür kitaplara yöneldikleri konusunda bilgiler içermektedir. Baraz (1987), 0-6 yaş aralığını "okulöncesi dönemi”; 7-9 yaş aralığını "masal dönemi”; 10-12 yaş aralığını ise "serüven dönemi” olarak ayırmıştır.

Okula başlamadan önce ailesi ve yakın çevresi dışında sınırlı bir iletişim alanına sahip olan çocuk, dinledikleri ve izlediklerinin yardımıyla farklı yaşantı örnekleriyle karşılaşır ve yaşama ilişkin deneyimlere tanıklık etmeye başlar. Olayların kahramanlarıyla özdeşim kurarak çatışmaları çözmeye çalışır. Tüm bunlar onun düş gücü destekleyerek farklı bakış açıları kazanmasına; böylelikle yaratıcı ve eleştirel düşünme becerilerinin gelişmesine olanak sağlar. Bundan dolayı, çağdaş toplumların gerek duyduğu demokratik kültür bilincine sahip, kendini gerçekleştirmeyi amaç edinmiş, yaşama çok boyutlu bakan ve eleştirel düşünen bireylerin yetişmesinde çocuk edebiyatı ürünlerinin önemli bir payı olduğunu söylemek mümkündür. İnsanın toplumsallaşma sürecinde evrensel ve ulusal değerleri içselleştirmesi açısından da çocuk edebiyatı önemli bir kaynaktır. Sevgi, saygı, barış, duyarlık, sorumluluk, erdem, dürüstlük, özveri gibi değerlerin soyut kavramlar olduğu düşünüldüğünde, çocuk edebiyatı yapıtları somut işlemler dönemindeki (6-12 yaş) çocukların bu değerleri somutlaştırması açısından önemlidir. $\mathrm{Bu}$ çalışmanın amacı, çocuk edebiyatı alanına nitelikli yapıtlar kazandırmış Aytül Akal'ın masallarında, Türkçe Dersi Öğretim Programında yer alan kök değerlerle ilişkisini belirlemek; bu değerlere ne ölçüde yer verildiğini ortaya koymaktır. Aytül Akal, yazarlık yaşamı boyunca edebiyatımıza çocukların ilgi ve gereksinmelerine uygun masal, öykü, roman, şiir, tiyatro türlerinde çok sayıda yapıt kazandırmıştır. Özellikle okulöncesi dönem ve ilkokul çağındaki çocuk okurların yazarın yapıtlarına ilgi duydukları söylenebilir. Yapıtlarının baskı sayılarının çokluğu da bu durumu destekleyebilir. Bu nedenle, yazarın çocuk edebiyatı yapıtlarının içerdiği kök değerler bakımından incelenmesi önemli görülmüştür.

Alanyazın tarandığında "değerler eğitimi / değer eğitimi / değer aktarımı" üzerine yapılmış 293 yüksek lisans, 42 doktora tezi olmak üzere toplam 335 lisansüstü tezle karşılaşılmaktadır. ${ }^{1}$ Bunlar arasında

\footnotetext{
${ }^{1}$ En son tarama 23.04.2020 tarihinde yapılmıştır.
} 
çocuk ve gençlik edebiyatı yapıtlarındaki değerleri inceleyen tezlerin sayısı da azımsanmayacak düzeydedir (Çelikten, 2019; Yeniay, 2019; Kavakl1, 2019; Baran Yir, 2019; Başar, 2019; Tursun, 2019; Abac1, 2018; Tokcan, 2017; Gürsoy Tavuş, 2015; Oran, 2015; Türkyılmaz, 2012; Kumbasar, 2011; Gökçe, 2008). Fatih Tokcan'ın (2017) “Fazıl Hüsnü Dağlarca'nın Çocuk Şiirlerinin Değerler Eğitimi Açısından İncelenmesi” adlı yüksek lisans tezinde, Dağlarca'nın çocuklar için yazdığı 7 şiir kitabında yer alan 422 şiir değerler eğitimi açısından incelenmiştir. İncelemede MEB'in öğretim programlarındaki değerler dikkate alınarak 23 değeri kapsayan bir dizelge oluşturuşmuş ve incelenen şiirlerde değerlere yönelik toplam 479 ileti belirlenmiştir. En çok "sevgi” değerinin yer aldığı şiirlerde, en az ise "sabır" ve "konukseverlik" değerlerine yer verildiği görülmüştür. Erdem Abacı'nın (2018) "Behiç Ak'ın Çocuk Kitaplarının Değerler Eğitimi Açısından İncelenmesi” başlıklı yüksek lisans tezinde, yazarın 29 çocuk kitabı 2006, 2015, 2018 yıllarında yayınlanan Sosyal Bilgiler dersi öğretim programından yararlanılarak belirlenen 63 değer bakımından incelenmiştir. Kitaplarda en sık "sevgi, çalışkanlık, dostluk" değerlerinin işlendiğine; en düşük oranda ise "vatandaşlık bilinci, cömertlik, çağdaşlık" değerlerine yer verildiğine ulaşılmıştır. Ezgi Kumbasar'ın (2011) "Muzaffer İzgü’nün Romanlarının Değerler Eğitimi Açısından İncelenmesi" adlı yüksek lisans tezinde, İzgü’nün 1971-2003 y1llarında yayımlanan 12 romanı yine Sosyal Bilgiler dersi öğretim programında yer alan değerler arasında seçilmiş 25 değer bakımın ele alınmıştır. Romanlarda en çok "sevgi, saygı, yardımlaşma"; en azsa "barış, cesaret, alçakgönüllülük" değerlerine yer verildiği görülmüsstür. Gülşen Oran'ın (2015) "Yalvaç Ural'ın Çocuk Kitaplarında Değerler Eğitimi ve Bu Eserlerin Türkçe Öğretimine Katkısı" başlıklı yüksek lisans tezinde, örneklem olarak Ural'ın 30 çocuk kitabı araştırmacı tarafindan belirlenen 10 değer açısından incelenmiştir. Kitaplarda, belirlenen değerlerle doğrudan ve dolaylı olarak ilişkili 525 ileti saptanmıştır. Yazarın kitaplarında "sevgi, sorumluluk, yardımlaşma, doğruluk" değerlerine sıklıkla yer verirken; en az "adalet, saygı, hoşgörü, yurtseverlik" değerlerini işlediği ortaya konmuştur. Tuğba Kavaklı'nın (2019) "Mavisel Yener'in Masal Kitaplarının Değerler Eğitimi Açısından İncelenmesi" adlı yüksek lisans tezinde, yazarın 34 masalı içerdiği değerler bakımından ele alınmış ve bu masalların değer eğitimi sürecine katkısını belirlemek amaçlanmıştır. Masallarda "sabır, sevgi, dürüstlük, özgüven, dostluk, duyarlılık, güven, cesaret, hoşgörü” başta olmak üzere toplam 39 değer saptanmıştır. Çalışma sonucunda, Yener'in masallarının, öğrencilerin değer eğitimi sürecini destekleyecek nitelikte olduğu belirlenmiştir.

Yukarıda adı geçen tezlerde görüldüğü gibi Türkçe eğitimi ve edebiyat alanlarında değerler eğitimi çalışmaları, genellikle tek bir yazarın kitaplarının betimsel araştırma yöntemleriyle incelenmesine dayanmaktadır. Ancak bunlardan ayrı olarak Mustafa Türkyılmaz'ın (2012) "Gençlik Romanlarının Okuma Becerisine Etkisi ve Değer Aktarımı Bakımından İncelenmesi” adlı doktora tezinde, farklı yazarların gençlik edebiyatı romanları içerdiği değerler açısından ele alınmıştır. Çalışma kapsamında ögrencilere okutulmak üzere 10 gençlik romanı seçilmiş ve bu romanlarda yer alan/aktarılan değerler belirlenmiştir. Romanlarda sevgi, dürüstlük, bilimsellik, hoşgörü ve sayg1 değerlerine daha çok; yurtseverlik, duyarlılık, barış değerlerine daha az yer verildiği görülmüştür. Gerek bu çalışma gerekse daha önce belirtilen çalışmaların ortak yanı, incelenen yazınsal yapıtlar en sık işlenen değerin "sevgi" olduğu dikkat çekmektedir.

YÖK Tez Merkezi veritabanında Aytül Akal ve yapıtlarına ilişkin yüksek lisans düzeyinde 9 tez bulunmaktadır. Bunlardan 5'inde Aytül Akal'ın yapıtlarındaki evrensel ve ulusal değerler tespit edilerek değerler eğitimine katkısı bakımından yorumlanmıştır (Gümüş, 2017; Çelebi, 2018; Yılmaz, 2018; Senek, 2018; Akıncı, 2019). Bu çalışmalar dışında, Eskişehir Osmangazi Üniversitesi Fen Edebiyat Fakültesi tarafindan 9-11 Mayıs 2012 tarihlerinde V. Ulusal Çocuk ve Gençlik Edebiyatı Yaşayan Yazarlar Dizisi kapsamında Aytül Akal Sempozyumu gerçekleştirilmiştir. Aytül Akal'ın edebî kişiliği ve yapıtları üzerine çok sayıda çalışmanın sunulduğu sempozyumun sonrasında, 63 bildirinin tam metin olarak yer aldığı sempozyum kitabı yayımlanmıştır. Kitaptaki bildirilerin konuları ise Aytül Akal'ın yapıtlarının biçimsel ve içerik özellikleri; yazarın yapıtlarında kültürel ögeler ve kültür aktarımı; yazarın yapıtlarında fantastik ögeler, fantastik ortamlar; çocukların sosyal gereksinimleri ve gelişim süreçlerine katkısı bakımından yazarın kitapları; yazarın kitaplarında karakterler, anne-çocuk ilişkisi, kuşak farklılıkları, çocuk eğitimi ve aile etmeni; yazarın yapıtlarında doğa-insan ilişkisi, doğa ve çevre algısı; yazarın şiirlerinde anlam evreni, söz ve anlam sanatları; yazarın yapıtlarının söz varlığı ve dil-anlatım boyutu; kitaplardaki toplumsal, eğitsel, duygusal iletiler ve bu iletilerin aktarım biçimleri; yazarın yapıtlarındaki bilişsel ögeler; yazarın kitaplarına çocuk gözüyle bakmak, çocuk gerçekliği ve çocuğa 
görelik, çocuk hakları; kitapların metindilbilimsel ve göstergebilimsel çözümlemesi; yapıtların estetik yönü ve resim-metin ilişkisi; klasik masallarla Aytül Akal masallarının karşılaştırılması, benzerlikler ve farklılıklar; yazarın yapıtlarında çocuk ve genç imgesi; yazarın kitaplarının Türkçe dersinde kullanımına yönelik değerlendirmeler. Sıralanan bu konular dışında, sempozyum kitabında "değerler" üzerine iki bildiri yer almaktadır. Bunların biri Esra Karakuş Tayri ve arkadaşları tarafından hazırlanan "Aytül Akal'ın Kitaplarında İş̧lenen Değerler" adlı bildiridir. Çalışmada yazarın öykü ve masalları seçkisiz örnekleme yoluyla belirlenmiştir. Toplamda 10 öykü ve 3 masal, işlediği değerler açısından incelenmiştir. Araştırma kapsamında yer alan 10 öyküde "estetik, sevgi, bilimsellik, çalışkanlık, yardımlaşma ve dayanışma, dürüstlük, aile birliği, sorumluluk, vatan sevgisi, duyarlılık, temizlik, adalet, sayg1, özgürlük, hoşgörü" değerlerinin; incelenen 3 masalda da "sevgi, saygı, arkadaşlık, duyarlılık, sorumluluk, çalışkanlık, yardımlaşma, dayanışma" değerlerin işlendiği ortaya konmuştur. Sempozyum kitabında yer verilen diğer bildiri ise Ahmet Mocan'ın "Aytül Akal'ın Öykü Kitaplarında Yer Alan Değerler" başlıklı çalışmasıdır. Bu çalışmada Akal'ın 8 öykü kitabı, içerdiği değerler açısından ele alınmıştır. İnceleme sonucunda yazarın öykülerinde "sevgi, takdir etme, sorumluluk, yardımlaşma, sabır, azim, dürüstlük, arkadaşlık, çalışkanlık, eşitlik, özgüven sahibi olma, alçak gönüllülük, itaatkârlık, kanaatkârlık, misafirperverlik, özeleştiri yapma, saygı" olmak üzere toplam 17 değerin yer aldığı görülmüştür. Adı geçen çalışmalardan ayrı olarak bu çalışmanın amacı ise Akal'ın çağdaş masallarını, Türkçe Dersi Öğretim Programındaki kök değerler çerçevesinde incelemek ve masalların bu kök değerlerle örtüşüp örtüşmediğini ortaya koymaktır.

\section{YÖNTEM}

Bu çalışma, tarama ve doküman incelemesi yöntemlerinin kullanıldığı nitel bir araştırmadır. Veriler, nitel araştırma yöntemlerinden doküman incelemesi yoluyla toplanmıştır. Doküman incelemesi, araştırılması hedeflenen olgu ya da olgulara ilişkin bilgi içeren yazılı araç gereçlerin çözümlenmesini kapsamaktadır (Yıldırım ve Şimşek, 2013, s.217). Çalışmada, Aytül Akal'ın toplam 58 masalı, Türkçe Dersi Öğretim Programında yer verilen kök değerlerle ilişkisi açısından ele alınmıştır. Yazarın masallarında belirlenen ulusal ve evrensel değerler, ilişkili olduğu kök değer altında kodlanmış ve yorumlanmıştır. 2019 yılı Türkçe Dersi Öğretim Programında (1-8.sınıflar) belirtilen "adalet, dostluk, dürüstlük, özdenetim, sabır, saygı, sevgi, sorumluluk, vatanseverlik, yardımseverlik" kök değerleri ve bunların masallardaki kullanım örnekleri, çalışmanın bulgular bölümünde ayrıntılı biçiminde sunulmuştur.

Çalışmanın geçerliliğini sağlamak amacıyla, Aytül Akal'ın 6 bölümden oluşan Masal Masal adlı kitabından örneklem çekilmemiş; tüm masallar (58 masal) değerlendirmeye alınmıştır. Çalışmada veri güvenirliğini sağlamak içinse yazarın kitabı, asıl araştırmacı tarafından farklı bir zamanda yeniden kodlanarak veriler kontrol edilmiştir. Ayrıca çalışmanın güvenilirliğini ve nesnelliğini artırmak amacıyla kitap, asıl araştırmacıyla eşzamanlı olarak Türkçe eğitimi alanında uzman başka bir araştırmacı tarafından da incelenmiş ve kodlanmıştır. Daha sonra veriler karşılaştırılarak iki araştırmacı arasındaki uyuşum yüzdesi hesaplanmıştır. İçsel tutarlılığı ortaya koyan bu kodlama denetiminde, kodlayıcılar arası görüş birliğinin en az \%80 olması beklenmektedir (Miles ve Huberman 1994'ten akt. Baltac1 2017, s.8). $\mathrm{Bu}$ çalışmada uygulamacılar arasındaki uyuşum oranı güvenirlik katsayısı $=$ görüş birliği $\div$ (görüş̧ birliği + görüşs ayrılığı) x 100 formülüyle hesaplanmış ve \%90'lık görüş birliğine ulaşılmıştır. Bu oranın alanyazında belirtilen orandan yüksek olması, çalışmada elde edilen verilerin yeterli güvenirliğe sahip olduğunu göstermiştir.

\section{BULGULAR}

Çalışmada, Aytül Akal'ın tüm masallarının toplandığı 6 bölümden oluşan Masal Masal adlı yapittaki toplam 58 masal, Türkçe öğretimindeki kök değerler çerçevesinde incelenmiştir. Bu nedenle bulgular arasında yazarın masallarındaki tüm değerler sıralanmamış; yalnızca kök değerlerle ilgili örneklere yer verilmiştir. Masallarda, 2019 y1lı Türkçe Dersi Öğretim Programında belirtilen "adalet, dostluk, dürüstlük, özdenetim, sabır, saygı, sevgi, sorumluluk, vatanseverlik, yardımseverlik" kök değerlerinden hepsine yönelik bulgulara ulaşılmıştır. Bu değerler alfabetik olarak sıralanmış; masallardan örnekler sayfa numaralarıyla gösterilmiştir. 


\section{Adalet}

Adalet kavramı Türkçe Sözlük'te "Yasalarla sahip olunan hakların herkes tarafından kullanılmasının sağlanması", "Hak ve hukuka uygunluk" ve "Herkese kendine uygun düşeni, kendi hakkı olanı verme" olarak tanımlanmaktadır. Bu bağlamda adalet terimi etik, hukuk, eşitlik, doğruluk gibi pek çok kavramla ilişki içerisindedir.

Aytül Akal'ın masallarında da adalet kavramıyla ilişkili olarak doğruluktan ayrılmayan, yasalara ve topluma saygı duyan, çevresindekilere eşit ve adil davranmaya çalışan karakterlere yer verildiği görülmüştür. Örnekler aşağıda sıralanmıştır.

“ 'Hem annenizin sözünü dinlemiyor hem de arkasından gülüyorsunuz. Oysa anneniz yalnızca sizin iyiliğinizi düşünüyordu. Ben sizinle oynamıyorum işte!' demiş su aygırı... Ertesi gün oynamak için tekrar ormana gittiğinde ne kurbağayı bulmuş, ne de timsahı. Meğer bir gün önce gölde yüzdükleri için üşütüp ikisi de hastalanmış. İyileşene kadar uzun süre evlerinden çıkamayacaklarmış. Küçük su aygırı 'İyi ki ben annemin sözünü dinlemişim,' demiş içinden. Küçük kurbağa ve timsah hasta yatarken, küçük su aygırı yeni arkadaşlarıyla güzel güzel oynamış.” (s.47)

“ 'Eğer üşütüp hastalansaydınız, ilaç verip sizi iyileştirebilirdim. Ama size yardım edemem. Kavgacılığınız yüzünden birbirinizin güneşini engellemiş, köklerinizi aynı yere uzatıp birbirinizin besinini almışsınız,' demiş." (s.87)

"Yalnızca bütün oyuncaklara sahip olmak isteyen çocuğun oyuncakları sabah olduğunda eve geri dönmemişler. Onlar gökyüzünde kalmışlar... Çocuk oyuncaklarını çok özlemiş. 'Bir daha kimsenin oyuncaklarını izinsiz almayacağım,' diye söz vermiş kendi kendine." (s.144)

“ 'Ama bu haksızlık!' diye bağırmış bütün hayvanlar. 'Çiçeksiz orman olur mu? Çiçeklerimizi geri ver!' Ayı karşı çıkmış 'Siz mışıl mışıl uyurken ben çalıştım, çiçek topladım. Tembellik etmek yerine siz de çalışın, kendinize bir iş bulun.' Tüm hayvanlar, şaşkın, öylece kalakalmış. Ne yapacaklarmış şimdi?” (s.228)

\section{Dostluk}

Dostluk sözcüğü Türkçe Sözlük’te "Sevme, güvenme, yakın arkadaş ve gönüldaş olma durumu” olarak tanımlanmıştır. Akal'ın masallarında da arkadaşlı̆ga ve dostluğa önem veren, birbirine güvenen ve yardım eden karakterlere yer verilmiştir. İlgili örnekler aşağıdadır.

"Böylece zürafa, kuş ve tavşan arkadaş olmuş. Akşam olup güneş batana kadar oynamışlar." (s.30)

"Küçük kurbağa ve küçük timsah hasta yatarken, küçük su aygırı yeni arkadaşlarıyla güzel güzel oynamış, çok eğlenmiş." (s.47)

“ 'En iyisi ayçöreği olayım,' diye düşünmüş. 'Burada bir sürü arkadaş var bana.' Diğer ayçöreklerinin yanına, tepsiye uzanmış." (s.60)

"O günden sonra canı sıkılan Ay, her gece yıldızlara masallar anlatmış. Artık yapacak bir işi ve konuşacak Arkadaşları olduğundan canı hiç ama hiç sıkılmamış." (s.62)

"Uzaylı çocuk, Dünyalı arkadaşlarına teşekkür edip uçan dairesine binmiş. Eve dönerken yolda, defterine 'Çalışarak her istenen elde edilebilir,' yazmış. Sonra gülümseyerek 'Arkadaşlık çok güzel bir duygu,' diye eklemiş.” (s.166)

\section{Dürüstlük}

Dürüstlük Türkçe Sözlük’te "Sözünde ve davranışlarında doğruluktan ayrılmama, doğruluk” biçiminde tanımlanmıştır. Dürüstlükle ilişkili olan kavramlar güvenilirlik, açıklık, doğru sözlülük olarak sıralanabilir. Akal'ın masallarında dürüstlük değeriyle ilgili aşağıdaki örnek yer almaktadır. 
"Anneciğim ben aslında kızamık değilim. Hemen okula yetişmeliyim, zaten çok geç

kaldım," diyerek annesinin yanağına hortumuyla tatlı bir öpücük kondurmuş." (s.151)

\section{Özdenetim}

Türkçe Sözlük'te özdenetim "Daha önemli bir amaca ulaşabilmek için kişinin tepkilerini, davranışlarını veya başka amaca yönelme eğilimini denetleyip kısıtlaması, otokontrol" biçiminde tanımlanmıştır. Kişinin davranışlarını kontrol etmesi, yaptıklarının sorumluluğunu yüklenmesi ve sonuçlarına katlanması gibi durumlar özdenetim ile ilişkilidir. Akal'ın masallarında özdenetim değerine yönelik bulunan örnekler aşağıdadır.

"Ama artık havanın kararmaya başladığını, güneşin onlara el salladığını önce zürafa görüyor, 'Haydi arkadaşlar, artık eve dönme saati geldi,' diyormuş." (s.33)

"Uzaylı çocuk her zaman meraklı bir çocuk olmuş. Ama merak etmekle zarar vermek arasında önemli bir fark olduğunu artık çok iyi biliyormuş. Merak ettiğini önce soruyor, sonra karıştırıyormuş." (s.49)

“ 'Hem annenizin sözünü dinlemiyor hem de arkasından gülüyorsunuz. Oysa anneniz yalnızca sizin iyiliğinizi düşünüyordu. Ben sizinle oynamıyorum işte!' diyerek yere attığı beresini başına geçirmiş, atkısını boynuna dolamış ve evine dönmüş." (s.47)

“ 'Hayır, beni beklemeyin! Ben artık büyüdüm! Bundan sonra kendi yatağımda uyumak istiyorum. İyi geceler!' demiş küçük fill.” (s.188)

"Yaramaz trafik lambası, her zaman çok merak etmiş. Aynı anda her yöne bütün 1şıklarını yaksa ne olurmuş acaba? Merak etmiş, etmiş ama, yaramaz trafik lambası bunu hiç denememiş." (s.198)

\section{Sabır}

Türkçe Sözlük’te "Acı, yoksulluk, haksızlık vb. üzücü durumlar karşısında ses çıkarmadan onların geçmesini bekleme erdemi, dayanç" olarak tanımlanan sabır değeri de Akal'ın masallarında yer almaktadır. Örnekler aşağıda verilmiştir.

"Bütün hayvanlar sabırla filin susmasını beklemiş. Fil susacak ki onlar da uyuyabilsin." (s.13)

“ 'Kendim olmak istiyorum. Önce çocuk olacağım, sonra herkes gibi ben de yavaş yavaş büyüyeceğim. Nasıl olsa ağabey de olacağım, baba da. Neden acele edeyim,' demiş.”' (s.26)

"O günden sonra zürafa günlerce hasta yatmış. İyileşene kadar dışarıya çıkamamış. Arkadaşları kuş ile tavşan neşe içinde oynarken o, evinde iyileşmeyi bekliyormuş." (s.33)

"Canı sıkılan bir çocuk varmış. Ne yapsa çabucak bıkıyor, nereye gitse sıkılıyormuş. 'Oyuncaklarınla oynasana,' demiş annesi. 'Oyuncaklarım güzel değil,' demiş çocuk. 'Arkadaşlarını ara, çağır birlikte oynarsınız,' demiş annesi. 'Onlarla küsüm, onlar oyuncaklarımla oynuyor, benimle değil!' demiş canı sıkılan çocuk. 'Peki otur masanın başına, kalemlerini getireyim, resim yap!' demiş anne sabırla. (s.57)

"Kim bilir, belki sizin dilekleriniz de hemen yerine gelir. Ama henüz gerçekleşmemişse de sakın üzülmeyin. Nasıl olsa ilerde dileklerinizin gerçekleşeceği günler gelecektir. O günlere kadar sabırlı olmalı ve ağaçları çok sevmelisiniz.” (s.223)

\section{Saygı}

Sözlük anlamı "Değeri, üstünlüğ̈̈, kutsallığı dolayısıyla bir kimseye ya da bir şeye karşı dikkatli, özenli, ölçülü davranmayı sağlayan sevgi duygusu" olan saygı kavramı; tüm insanlara ve topluma değer verme, çevresindekilere kibar ve duyarlı bir biçimde davranma, kibir ve kabalıktan uzak olma gibi durumları da beraberinde getirmektedir. İncelenen masallarda saygı değerine ilişkin örnekler şöyledir:

"O günden sonra gece ile gündüzü hiç karıştırmamış. Gündüzleri oynamış, geceleri uyumuş. Uyumak isteyenleri hiçbir zaman rahatsız etmemiş." (s.15) 
"Burada yuvan olduğunu bilmiyordum. Öyleyse ben de başka bir ağacın yapraklarını yerim." (s.30)

"O büyüdüğü zaman bütün trafik kurallarına uyacak, araba kullanırken başkalarına saygılı olmayı hiç unutmayacakmış." (s.65)

"Oldu mu şimdi? Eğlenmek isterken başkalarını rahatsız etmesi başına ne işler açacakmış böyle?" (s.198)

\section{Sevgi}

Sevgi kavramı Türkçe Sözlük'te "İnsanı bir şeye veya bir kimseye karşı yakın ilgi ve bağl1lık göstermeye yönelten duygu" olarak tanımlanmıştır. Aytül Akal'ın masallarında insan sevgisi, doğa sevgisi, hayvan sevgisi sık sık işlenmiştir. İnceleme sonucunda, yazarın masallarında en çok sevgi değerine ilişkin bulgulara yer verildiği görülmüştür. Masallardan alıntılanan örnekler aşağıda sıralanmıştır.

“Annesi onu kucağına alıp 'Benim canım bebeği,' diye saçlarını okşarmış.” (s.21)

“O günden sonra hep o parkta, diğer ağaçlarla birlikte yaşamış. Çöplükleri değil; ağaçları, çiçekleri ve güzel doğayı sevmiş." (s.74)

" 'Tabii güzel güzel büyütürüz anne! Bak, ben onu şimdiden seviyorum,' diye atılmış çocuk." (s.100)

"Annesi onu kucağına almış. Saçlarını öpmüş okşamış. 'Sen olmasan ben ne yapardım?

Dilerim kardeşin de büyüdüğünde sana benzer,' demiş.” (s.105)

"Küçük çocuk, hayvanları da çok severmiş. Hayvanlarla oynamak istediğinde, annesi o gece ona rüya ormanını verirmiş." (s.145)

"Eğer bir gün renksiz, eski bir top görürseniz bilin ki renklerin seçildiği güne yetişememiştir. Siz onu yine de sevin, onunla oynayın.” (s.155)

“İki küçük kardeş varmış. Bizim sokağımızdaki evlerden birinde yaşarlarmış. Bu iki kardeşi birbirlerini çok severmiş.” (s.167)

“ 'Bir dakika! Ben şimdi anladım! Annem her zaman ne söylerdi, hatırlasana. İkinizi de çok seviyorum demez miydi?' demiş büyük kardeş.” (s.169)

“Annesi gülmüş. 'Sevmek sınırsızdır yavrum,' demiş çocuğu kucaklayarak. 'Herkesi, hatta tüm dünyayı sevebilirsin. Yüreğimizde herkese, her şeye yer var.' ” (s.179)

“ 'Biz hep böyle eğleniriz,' demiş orman cüceleri. 'Bizler doğayı çok severiz. Onun için doğada yaşar; çiçeklerle, ağaçlarla oynarız.' " (s.231)

"Çok kolay! Önce insan olmayı öğreneceksin. İyi yürekli, yardımsever ve sevgi dolu bir insan.” (s.236)

\section{Sorumluluk}

Sözlük anlamı "Kişinin kendi davranışlarını veya kendi yetki alanına giren herhangi bir olayın sonuçlarını üstlenmesi, sorum, mesuliyet" olan sorumluluk değeri Akal'ın masallarında sıklıkla işlenmiştir. Masallardan örnekler aşağıda sunulmuştur.

“O günden sonra da giysilerini, kitaplarını, oyuncaklarını hep yerlerine kaldırmış.” (s.54)

“ 'Büyüdüğümde ben de mutlaka yabancı dil öğrenmeliyim. Bunun için derslerime çok çalışacağım,' demiş kendi kendine.” (s.64)

"Çocuğun korkudan yüreği ağzına gelmiş. Böyle de araba kullanılır mımış? O büyüdüğü zaman bütün trafik kurallarına uyacak, araba kullanırken başkalarına saygılı olmayı hiç unutmayacakmış." (s.65)

"Sonunda kala kala bir tek park kalmış. O yörenin çocukları, kendi parklarının da çöplüğe dönüşmesinden çok korkuyormuş. Çevresinde nöbet tutarak parklarını korumaya karar 
vermişler. Birer ikişer aralıklarla parkı çepeçevre sarmışlar. Onlara görünmeden parklarına kimsecikler giremezmiş artık." (s.74)

"Uzaylı çocuk açıklamış 'Bu makineler bütün pislikleri temizler. Biz fabrikayı kurmadan önce, ilk iş olarak bu temizleme makinelerini yaparız. Yoksa ülkemiz kirlenir, bütün güzellikler renklerini, canlılığını kaybeder.' "(s.84)

"Uykuya dalmadan önce, sabah erkenden uyanıp derslerini tamamlamaya ve bundan böyle her gün ödevlerini düzenli yapmaya kendi kendine söz vermiş." (s.91)

"Yırtamaz ki! Ben kitaplarımı, defterlerimi hiç ortalarda bırakmam. Onun ulaşamayacağ 1 yerlere kaldırırım." (s.100)

"Küçük çocuk çok akıllı bir çocukmuş. Derslerini düzenli çalışır, bilmediği konuları ansiklopedilerden araştırırmış." (s.112)

"Küçük vapur artık çok mutluymuş. Sabahları erkenden kalkıyor ve işe gidenleri işe, okula gidenleri okula götürüyormuş. Çocukların anlattığı dersleri dinliyor, onların neşesiyle o da neşeleniyormuş. En sevindiği şey de çocukları denize hiç çöp atmamalarıymış. Çocuklar büyüdükleri zaman da denize çöp atmayacaklarmış." (s.113)

"Küçük dinozor evine ulaşmasına ulaşmış da o garip gezegeni hiç unutmamış. Ne zaman yerinden kalkmaya üşense, aklına hemen kafeslerdeki tembel ayvanlar geliyormuş. İște o zaman yerinden firlayıp tüm işlerini çabucak yapıyormuş" (s.129)

“ ‘Aaa, şuraya bak! Yere bir kâğıt parçası düşmüş,' demiş çocuklardan biri. 'Haydi kaldırıp çöpe atalım.' Uzanıp kâğıdı yerden almış. Diğer çocuk 'Peki ama neden kaldırıyormuşuz ki? Büyüklerin işi değil mi bu?' diye karşı çıkmış. Kâğıdı kaldıran çocuk, arkadaşına 'Bizim de büyüdüğümüzde sayısız sorumluluğumuz olacak,' demiş. ' $O$ zaman bizim gözümüzden kaçan işleri de çocuklarımız üstlenir.' 'Haklısın,'demiş arkadaşı. Kâğıdı çöpe atmışlar. Buruşuk kâğıt parçası çok mutlu olmuş." (s.162)

"Ertesi gün, çöpler konusunda çok dikkatli davranmış. Üstelik yalnız kendi çöplerini toplamakla kalmamış, yere çöp atanları gördüğünde onları da uyarmış." (s.200)

"Çocuksun ama birçok büyükten dikkatlisin. Çevreni inceliyor, her değişikliği fark ediyorsun. Sem arkadaşlarımızın ışığının söndüğünü fark edemeyen büyükleri uyar, yeter." (s.212)

'Peri de cüceler de çok şaşırmışlar. 'Doğa bize küstü mü?' diye sormuş orman cüceleri. 'Öyle olmalı,' demiş orman perisi. 'Siz doğaya zarar veriyordunuz. Şimdi sizden kaçıp gizleniyor işte!' Ormanın yeni komşuları o günden sonra doğayı sevmenin, onu korumak olduğunu anlamışlar.” (s. 233)

\section{Vatanseverlik}

Türkçe Sözlük’te “yurdunu ve milletini büyük bir tutkuyla sevme, bu uğurda her türlü özveriye katlanma, yurtseverlik" olarak tanımlanan vatanseverlik; tarihsel ve doğal mirasa sahip çıkma, doğayı sevme ve onu koruma, topluma değer verme gibi durumlarla ilişkilidir. Akal'ın masallarında vatanı uğruna mücadele etme, bayrak sevgisi, kahramanlık gibi durumlara yer verilmemiştir. Ancak vatandaşlık görevlerimiz arasında yer alan doğa sevgisi ve duyarlılı̆̆ı, toprağına ve yaşadığı yere bağl1lık, doğal kaynakları ve güzellikleri koruma, çevre bilincine sahip olma, doğaya ve çevreye saygı duyma, ulusal zenginliklerimizi korumaya çalışma gibi durumların da vatanseverlik kavramıyla ilişkili olduğu düşünülürse, yazarın masallarında bu konulara yönelik örneklerle karşılaşılmıştır. Bunlardan bazıları aşağıda sıralanmıştır.

“ 'Ama çocuğum, evin bütün 1şıklarını açık bırakmışsın. Yazık değil mi?’ demiş annesi. 'İçerisi karanlıktı,' diye yakınmış çocuk. 'Tamam karanlıktı. Ama dönerken bütün 1şıkları söndürseydin ya! Hem bir sürü elektrik parası ödüyoruz hem de ülkemizin enerji zenginliğini boşa harcamış oluyoruz.' Çocuk annesine hak vermiş. O gece uyumak için 
yatağına giderken yürüyüp geçtiği her yerin 1şığını yakmak yerine, karanlıkta yürümeyi denemek istemiş." (s.49)

"Fil iyice şımarmış 'Bu orman benim!' diye gürlemiş bir gün. 'Herkes başka ormana gitsin. Bütün bu ağaçlar, bu meyveler, bütün bu çiçekler, topraklar... Hepsi, hepsi benim!' Hayvanlar çok şaşırmışlar. Şimdi ne yapsınlar? Fille hiçbiri başa çıkamazmış ki! Fil çok güçlüymüş. Hepsini birer birer yere serermiş. Çaresiz, toparlanıp ormandan ayrılmışlar. Kendilerine yeni bir yer bulmuşlar. Ama hiçbiri yeni evinden memnun değilmiş. Herkes eski evini ve ormanını özlüyormuş... Hayvanlar aralarında tartışırken bir de bakmışlar ki bir çocuk, kayanın ardına gizlenmiş onlara katıla katıla gülüyormuş. 'Neden gülüyorsun?' diye sormuşlar çocuğa. 'Siz hep kendinizi file karşı tek başına düşünüyorsunuz. Oysa hepiniz birlikte, filden yüzlerce kez güçlü değil misiniz?' demiş çocuk. Hayvanlar çok utanmış, çocuk haklıymış. Bütün hayvanlar el ele verip eski ormanlarına doğru yürümeye başlamışlar. Fil onları görünce korkup şımarıklıktan vazgeçmiş. Hayvanlar evlerine dönmüşler. Hep beraber mutlu mutlu yaşamışlar.” (s.68-70)

"Sonunda kala kala bir tek park kalmış. O yörenin çocukları, kendi parklarının da çöplüğe dönüşmesinden çok korkuyormuş. Çevresinde nöbet tutarak parklarını korumaya karar vermişler. Birer ikişer aralıklarla parkı çepeçevre sarmışlar. Onlara görünmeden parklarına kimsecikler giremezmiş artık." (s.74)

"Uzaylı çocuk açıklamış 'Bu makineler bütün pislikleri temizler. Biz fabrikayı kurmadan önce, ilk iş olarak bu temizleme makinelerini yaparız. Yoksa ülkemiz kirlenir, bütün güzellikler renklerini, canlılığını kaybeder.' "(s.84)

'Peri de cüceler de çok şaşırmışlar. 'Doğa bize küstü mü?' diye sormuş orman cüceleri. 'Öyle olmalı,' demiş orman perisi. 'Siz doğaya zarar veriyordunuz. Şimdi sizden kaçıp gizleniyor işte!' Ormanın yeni komşuları o günden sonra doğayı sevmenin, onu korumak olduğunu anlamışlar.” (s. 233)

\section{Yardımseverlik}

Türkçe Sözlük’te "Yoksullara, düşkünlere, yardıma muhtaç olanlara iyilik ve yardım etmeyi sevme durumu, iyilikseverlik, hayırseverlik" olarak tanımlanan yardımseverlik, Akal'ın masallarda sevgi değeri gibi en sık kullanılan değerlerdendir. Masallarda paylaşma ve dayanışmayı önemseyen, acıma ve vicdan duygusuna sahip karakterlere yer almaktadır. İlgili örnekler aşağıdadır.

“ 'İstersen ben önden uçup bakayım. Eğer yaprakların arasında gizlenmiş bir yuva varsa sana haber veririm.' Böylece kuş ve zürafa arkadaş olmuş. Kuş ona dallarında yuva olmayan ağaçların yerini göstermiş, zürafa da bol bol yaprak yemiş. Eğer yediği yaprakların üzerinde tırtıl varsa, o zaman zürafa haber veriyormuş kuşa. Kuş da tırtılı afiyetle yiyormuş." (s.30)

"Zürafa 'Bundan kolay ne var? Ben başımı eğeyim, sen tırmanıp boynuma tutun. Böylece ağaçların tepesinden çevreyi seyredebilirsin,' demiş.” (s.30)

“ 'Ben yalnızca küçük bir kertenkeleyim, yüzme bilmem. Kurtarın beni!' Küçük kertenkele böyle söyleyince timsahlardan biri uzun kuyruğunu uzatmış ve küçük kertenkeleyi alıp sahile bırakmış." (s.35)

"Uzaylı çocuğun parmakları çok güçlüymüş. Tek parmağıyla kamyonu çevirip düzeltmiş. Kamyon, motorunu çalıştırmış ve uzaylı çocuğa teşekkür edip yoluna devam emiş." (s.38)

"Robot dönüp çocuğa şaşkınlıkla bakmış. 'Ama ben size yardımcı olmaya çalışıyorum. Siz çöplükte oynamayı sevmez misiniz? Ben de buraları sizin içi çöplüğe dönüştürüyorum işte!' demiş." (s.74)

"Onlar evlerini kaybetmiş. Ben onların annesi oldum. Lütfen anneciğim izin ver, bu gece burada yatsinlar." (s.79) 
“ 'Ben size yardım edebilirim,' demiş solucan. Sonra arkadaşlarını çağırmış. Hep birlikte ağacın köklerine tünel açarak birbirine dolaşan kökleri ayırmışlar.” (s.88)

“ 'Para işini düşünme sen anneciğim,' demiş. 'Kardeşim için, bugüne kadar biriktirdiğim bütün parayı kullanabilirsin.' " (s.100)

'Fısıldayarak 'Sen git biraz dinlen anneciğim. Kardeşimi ben uyuturum,' demiş. Annesi onu kucağına almış. Saçlarını öpmüş okşamış. 'Teşekkür ederim yavrum. Buna gerçekten ihtiyacım vardı. Sen olmasan ben ne yapardım? Dilerim kardeşin de büyüdüğünde sana benzer.' " (s.105)

"Aralarından biri, bir fikir atmış ortaya. 'Eğer orada yaşayan çocuklar soru sormaya başlarsa, onlar da bizim gibi bol bol araştırır, durmadan kitap okurlar. Ne dersiniz, onlara yardım edelim mi?" " (s.172)

"Çok kolay! Önce insan olmayı öğreneceksin. İyi yürekli, yardımsever ve sevgi dolu bir insan." (s.236)

\section{TARTIŞMA VE SONUÇ}

Çalışmada, Aytül Akal'ın yazdığı çağdaş masalların toplandığı Masal Masal adlı yapıtta yer alan 58 masal, 2019 yılı Türkçe Dersi Öğretim Programında belirtilen "kök değerler" çerçevesinde incelenmiştir. İncelenme sonucunda, masallarda 10 kök değerin tamamının işlendiği görülmüştür. Çalışmanın amacı, yazarın masallarında hangi değerin daha sık kullanıldığını belirlemek değil; kök değerlere yer verilip verilmediğini ortaya koymak olsa da masallarda en sık işlenen kök değerlerin sırasıyla "sevgi, yardımseverlik, sorumluluk" olduğuna da belirtmek gerekir. Yazarın masallarında işlenen "sevgi" değerinin insanlara duyulan sevgi, hayvan sevgisi, doğa sevgisi, yurt sevgisi gibi farklı alanlara yönelik ve geniş boyutta olduğu dikkat çekmektedir.

Akal'ın roman, öykü ve masallarındaki değerleri belirlemeye yönelik yapılmış diğer çalışmaların sonuçlarına bakıldığında da yazarın yapıtlarının değerler bakımından çok zengin ve çeşitli olduğu görülmektedir. Gümüş (2017), Akal'ın romanlarında “iyilikseverlik, geleneksellik, sevgi” değerleri başta olmak üzere toplam 44 değer; Çelebi (2018), yazarın 8 romanını değer aktarımı yönünden inceleyerek "dostluk" başta olmak üzere 31 değer; Yılmaz (2018), yazarın 14 romanında "duyarlılık" başta olmak üzere 30 değer; Karakuş Tayri vd. (2012), yazarın 10 öykü kitabında sevgi başta olmak üzere toplam 16 ve 3 masalında "yardımlaşma" başta olmak üzere 7 değer; Mocan (2012) ise yazarın 8 öykü kitabında "sevgi" başta olmak üzere toplam 17 değer olduğunun belirlemiştir. Akıncı (2019), yazarın 15 romanında en çok "sevgi", en az da "adalet" değerinin işlendiğini; Senek (2018), yazarın masallarında belirlediği 20 değer arasında en sık rastlanan değerin sevgi, en az yer alan değerin ise "doğruluk" olduğunu ortaya koymuştur. Senek'in çalışmasından farklı olarak bu çalışma, Akal'ın masallarında yer verilen değerleri saptamak değil; bu masallarda Türkçe Dersi Öğretim Programındaki kök değerlerin işlenip işlenmediğini belirlemek amacıyla yapılmıştır. $\mathrm{Bu}$ doğrultuda gerçekleştirilen inceleme sonucunda -yukarıda da aktarıldığı gibi- öğretim programındaki 10 kök değerin tamamının, Akal'ın masallarında yer aldığı görülmüştür. Masallarda en sık yer alan kök değerin -diğer çalışmalarının sonuçlarıyla paralel olarak- "sevgi" olduğu; bu değeri "yardımseverlik" ve "sorumluluk" değerlerinin izlediği; masallarda en az karşılaşılan kök değerin ise "dürüstlük" olduğu saptanmıştır.

Sever (2012, s.118) çocuk edebiyatı ürünleri okurunun özgüvenini geliştirecek, onu kahramanla özdeşim kurmaya itecek özelliklerin; kahramanın yaşamda başına gelen zorluklara karşı verdiği uğraşların, sorunlara uygun çözümler oluşturma becerisi geliştirmesini kolaylaştırdığını belirtmiştir. İncelenen masallar için de çocuk okurun, masal kahramanlarıla özdeşim kurarak kök değerleri içselleştirmesine olanak sağlandığını söylemek mümkündür. Ayrıca masallarda yer alan değerler, öğretici bir dil ve anlatımla değil; estetik ve fantastik kurgu içerisinde çocukların anlamlandırabileceği bir biçimde sunulmuştur. Yazarın bu yolla, masalı okuyan ya da dinleyen çocukların olayın içine daha kolay girerek karaktere eşlik etme sürecine yardımcı olduğu söylenebilir. Bu durum, çocuğun masallarda işlenen değerleri de daha eğlenceli bir yolla sezmesine ve edinmesine katkı sağlayabilir.

Hangi yazınsal türde olursa olsun çocuk edebiyatı yapıtları işlediği konu ve iletiler, yarattı̆̆ karakterler, dil ve anlatım biçimi vb. temel ögeler açısından, çocuk okurlara iyiye ve güzele ilişkin duyarlılıklar 
kazandırmaya; onların kavram ve anlam evrenini geliştirmeye; onların dilsel, bilişsel, duyuşsal, toplumsal gelişimleri ile kişilik gelişimlerini desteklemeye yönelik olmalıdır. Nitelikli çocuk edebiyatı ürünleri çocukların ulusal ve evrensel değerleri tanıyan, olumlu karakter özelliklerine sahip, demokratik kültür bilinci edinmiş çağdaş bireyler olarak yetişmeleri için zemin hazırlamalıdır.

Sonuç olarak bu çalışmada, Aytül Akal'ın çağdaş masallarında 2019 yılı Türkçe Dersi Öğretim Programında yer alan 10 kök değerin etkili ve özgün örneklerle işlendiği görülmüsstür. Bu değerlerden "sevgi, yardımseverlik, sorumluluk" değerlerinin ağırlıkta olduğu; en az "dürüstlük" değerine yer verildiği belirlenmiştir. Bu bağlamda yazarın masallarına yönelik Türkçe öğretiminde üzerinde durulan kök değerleri aktaran ileti ve örnekler içerdiği; bu değerler aracılığıyla çocukların değerler eğitimi sürecine katkı sağlayabileceği; bu masalların, birinci ve ikinci sınıf Türkçe derslerinde yararlanılabilecek bir kaynak niteliğinde olduğu söylenebilir.

Bilgilendirme / Acknowledgement:

1- Makalede doküman incelemesi yapıldığı için etik kurulu izni ve/veya yasal/özel izin alınmasını gerektiren bir durum yoktur.

2- Bu makalede araştırma ve yayın etiğine uyulmuştur.

\section{KAYNAKÇA}

Abacı, E. (2018). Behiç Ak’ın çocuk kitaplarının değerler eğitimi açısından incelenmesi. Yayımlanmamış yüksek lisans tezi, Bülent Ecevit Üniversitesi, Zonguldak.

Akal, A. (2016). Masal masal. Ankara: Uçanbalık Yayınları.

Akıncı, B. (2019). Değerler eğitimi açısından Aytül Akal'ın çocuk romanlarının incelenmesi. Yayımlanmamış yüksek lisans tezi, Sakarya Üniversitesi, Sakarya.

Aslan, C. (2019). Çocuk edebiyatı ve duyarlık eğitimi. Ankara: Pegem Akademi.

Baltac1, A. (2017). Nitel veri analizinde Miles - Huberman modeli. Ahi Evran Üniversitesi Sosyal Bilimler Enstitüsü Dergisi, 3(1), 1-15.

Baran Yir, B. (2019). Bilgin Adalı'nın eserlerinin değerler ĕgitimi açısından incelenmesi. Yayımlanmamış yüksek lisans tezi, Bülent Ecevit Üniversitesi, Zonguldak.

Baraz, T. (1987). Çocuk ve kitap. Eskişehir Anadolu Üniversitesi Açıköğretim Fakültesi Ders Kitapları. Eskişehir: Anadolu Üniversitesi Yayınları.

Başar, R. (2019). Behiç Ak'ın çocuk kitaplarında değer eğitimi ve bu eserlerin Türkçe ögretimine katkısı. Yayımlanmamış yüksek lisans tezi, Dumlupınar Üniversitesi, Kütahya.

Çelebi, V. (2018). Aytül Akal'ın çocuk romanlarının değerler eğitimi açısından incelenmesi. Yayımlanmamış yüksek lisans tezi, Gaziantep Üniversitesi, Gaziantep.

Çelik, Ö. ve Buluç, B. (2018). Disiplinler arası yaklaşımla değer öğretiminde yaratıcı drama yönteminin kullanılması. Erzincan Üniversitesi Ĕ̈itim Fakültesi Dergisi, 20(1), 67-88

Çelikten, F. (2019). Nezihe Meriç'in çocuk kitaplarının değerler eğitimi açısından incelenmesi. Yayımlanmamış yüksek lisans tezi, Marmara Üniversitesi, İstanbul.

Ekşi, H. (2003). Temel insani değerlerin kazandırılmasında bir yaklaşım: Karakter eğitimi programları. Değerler Ĕ̈itimi Dergisi, 1(1), 79-96.

Gökçe, B. (2008). Gülten Dayıoğlu'nun çocuk öykülerinde değerler eğitimi ve öykülerin Türkçeye katkısl. Yayımlanmamış yüksek lisans tezi, İnönü Üniversitesi, Malatya.

Gümüş, S. (2017). Değerler eğitimi bă̆lamında Aytül Akal’ın çocuk romanlarının analizi. Yayımlanmamış yüksek lisans tezi, Marmara Üniversitesi, İstanbul. 
Gürsoy Tavuş, Z. (2015). Gülten Dayıoğlu'nun hikâyelerinin değerler eğitimi açısından incelenmesi. Yayımlanmamış yüksek lisans tezi, Necmettin Erbakan Üniversitesi, Konya.

Kantar, Ş. (2014). İlköğretim 4 ve 5. sinıf sosyal bilgiler dersinde 100 temel eser yoluyla değerler eğitimi. Yayınlanmamış yüksek lisans tezi, Necmettin Erbakan Üniversitesi, Konya.

Karakuş Tayri, E., Özdemir, B. ve Karakuş Aktan, E. (2012). Aytül Akal'ın kitaplarında işlenen değerler. A. Gültekin, M. Sivri, Z. Çiftçi ve B. H. Yılmaz (Haz.), V. Ulusal Çocuk ve Gençlik Edebiyatı Yaşayan Yazarlar Sempozyum Dizisi - Aytül Akal Sempozyumu Bildiri Kitabı (s. 287296). İzmir: Uçanbalık Yayıncılık.

Kavaklı, T. (2019). Mavisel Yener'in masal kitaplarının değerler eğitimi açısından incelenmesi. Yayımlanmamış yüksek lisans tezi, Afyon Kocatepe Üniversitesi, Afyon.

Kavcar, C. (1999). Edebiyat ve eğitim. Ankara: Engin Yayınevi.

Kumbasar, E. (2011). Muzaffer İzgü’nün romanlarının değerler eğitimi açısından incelenmesi. Yayımlanmamış yüksek lisans tezi, Karadeniz Teknik Üniversitesi, Trabzon.

Millî Eğitim Bakanlığı (2019). Türkçe dersi öğretim programı. Ankara: Milli Eğitim Bakanlığı Yayınları.

Mocan, A. (2012). Aytül Akal'ın öykü kitaplarında yer alan değerler. A. Gültekin, M. Sivri, Z. Çiftçi ve B. H. Yılmaz (Haz.), V. Ulusal Çocuk ve Gençlik Edebiyatı Yaşayan Yazarlar Sempozyum Dizisi Aytül Akal Sempozyumu Bildiri Kitabı (s. 287-296). İzmir: Uçanbalık Yayıncılık.

Oğuzkan, F. A. (1993). Eğitim terimleri sözlüğ̈̈. Ankara: Emel Matbaacılık.

Oran, G. (2015). Yalvaç Ural'in çocuk kitaplarında değer ĕgitimi ve bu eserlerin Türkçe ögretimine katkısı. Yayımlanmamış yüksek lisans tezi, Uşak Üniversitesi, Uşak.

Senek, S. (2018). Aytül Akal’ın masallarının değerler eğitimi açısından incelenmesi. Yayımlanmamış yüksek lisans tezi, Akdeniz Üniversitesi, Antalya.

Sever, S. (2012). Çocuk ve edebiyat. İzmir: Tudem Yayınları.

Sever, S. (2015). Çocuk edebiyatı ve okuma kültürü. İzmir: Tudem Yayınları.

Talim ve Terbiye Kurulu Başkanlığı (2017). Müfredat yenileme ve değişiklik çalışmalarımız üzerine. Ankara: MEB Yayınları.

Tokcan, F. (2017). Fazıl Hüsnü Dağlarca'nın çocuk şiirlerinin değerler eğitimi açısından incelenmesi. Yayımlanmamış yüksek lisans tezi, Necmettin Erbakan Üniversitesi, Konya.

Tursun, G. (2019). Serpil Ural'ın çocuk kitaplarının değerler eğitimi açısından incelenmesi. Yayımlanmamış yüksek lisans tezi, Bayburt Üniversitesi, Bayburt.

Türk Dil Kurumu (2019). Türkçe sözlük. Ankara: TDK Yayınları.

Türkyılmaz, M. (2012). Gençlik romanlarının okuma becerisine etkisi ve değer aktarımı bakımından incelenmesi. Yayımlanmamış doktora lisans tezi, Gazi Üniversitesi, Ankara.

Yazıcı, K. (2006). Değerler eğitimine genel bir bakış. Türklük Bilimi Araştırmaları, 19, 499-522. 